\title{
Protecting the clean athlete, protecting health
}

\author{
Richard Budgett Dr \\ From World's Leading Rowing Sport Science and Medicine Conference - "Improving Performance Naturally" \\ Marlow, UK. 22-25 January 2015
}

The vision of the IOC is to change the world for the better through sport and to promote social change. Protecting the health of the athlete is an important part of this vision, in order to protect the integrity of sport, protect elite athletes, protect the health of all those exercising and to promote physical activity. The protection of clean athletes through doping control is also important for the protection of the integrity of sport and of athlete health. The focus of the IOC Medical Commission is the prevention of injury and illness; this is done through world conferences, injury and illness surveillance, International Federations (IF) and National Olympic Committees.

Rowing is an excellent example of a non-contact sport, where overuse injuries are the main problem. Illness and overtraining are also important. Individual physiology and training are crucial to develop the combination of power and endurance needed to compete. Rowing is a perfect sport for the multidisciplinary team of sport and exercise medicine, physiotherapy, physiology, psychology, nutrition and biomechanics specialists.

Priority for the IOC is surveillance and audit, so that changes to rules, to equipment, to training and to technique can be evidence based and the effect on prevention measured. It is important for different sport federations to take every opportunity to work with each other for cross fertilization of best practice and new ideas, including at the IOC IF meetings.

The IOC and world rowing share the priority of protecting health and protecting clean athletes.

Published: 11 August 2015

\section{References}

1. Budgett $\mathrm{R}$, Engebretsen $\mathrm{L}$ : The protection of clean athletes through the IOC research fund. Br J Sports Med 2015, 49:1.

2. Maughan RJ, Engebretsen L, Soligard T, Budgett R: The IOC Diploma programme in sports medicine. Br J Sports Med 2013, 47(13):812.

3. Rowing Injuries: Chapter in Sports Medicine. Oxford University Press; 2011, 502-505.

International Olympic Committee Medical and Scientific Director
4. Sports Medicine: Handbook of Sports Medicine and Science - Rowing Blackwell;:Niels H. Secher; Stefanos Volianitis 2007:124-140.

5. Budgett R, Fuller GN: Illness \& Injury in International Oarsmen. Clinical Sports Medicine 1989, 1:57-61.

doi:10.1186/2052-1847-7-S1-02

Cite this article as: Budgett: Protecting the clean athlete, protecting health. BMC Sports Science, Medicine and Rehabilitation 2015 7(Suppl 1):02.
Submit your next manuscript to BioMed Central and take full advantage of:

- Convenient online submission

- Thorough peer review

- No space constraints or color figure charges

- Immediate publication on acceptance

- Inclusion in PubMed, CAS, Scopus and Google Scholar

- Research which is freely available for redistribution
() Biomed Central 